\title{
PENERAPAN MODEL PEMBELAJARAN TGT UNTUK PENINGKATAN HASIL BELAJAR MATERI BILANGAN ROMAWI SISWA KELAS IV SEKOLAH DASAR
}

\author{
ELIYANI SARAGIH ${ }^{1}$, NELLY WEDYAWATI ${ }^{2}$ \\ ${ }^{1}$ STKIP Persada Khatulistiwa Sintang, Jl. Pertamina-Sengkuang, Sintang \\ eliyanisaragih@yahoo.com \\ ${ }^{2}$ STKIP Persada Khatulistiwa Sintang, Jl. Pertamina-Sengkuang, Sintang
}

First Received: 11-07-2019; Accepted: 28-10-2019

\begin{abstract}
Abstrak
Penelitian ini bertujuan untuk mendeskripsikan peningkatan hasil belajar siswa menggunakan model Teams Games Tournament (TGT) pada materi Bilangan Romawi pada kelas 4 SD 06 Sintang. Metode penelitian yang digunakan adalah penelitian deskriptif dengan pendekatan kualitatif, dalam bentuk penelitian tindakan kelas. Penelitian ini terdiri dari dua siklus. Masing-masing siklus terdiri dari empat tahap yaitu perencanaan, tindakan, observasi, dan refleksi. Instrumen penelitian yang digunakan adalah lembar observasi, tes, kuisioner, dan dokumentasi. Penelitian menghasilkan peningkatan hasil belajar siswa dengan model Teams Games Tournament (TGT) di siklus I dengan persentase total $63,33 \%$, untuk siklus II meningkat secara signifikan sebesar 90,90\%. Ini menunjukkan peningkatan hasil belajar siswa dari siklus I sampai siklus II sebesar $27,57 \%$.
\end{abstract}

Kata kunci: Belajar; Hasil; Teams Games Tournament

\section{THE APPLICATION OF THE TGT LEARNING MODEL IN IMPROVING LEARNING OUTCOMES OF ROMAN NUMERALS GRADE IV ELEMENTARY SCHOOL STUDENTS}

\begin{abstract}
This study is aim to describe improving student learning outcomes using models Teams Games Tournament (TGT) on the material of Bilangan Romawi the fourth grade students 06 Sintang. The method used in this research is descriptive research method with qualitative approach, in the form of classroom action research. This study was conducted in two cycles. Each cycle consists of the stages of planning, action, observation, reflection. Data retrieval tool is used in the form of guidelines for observation, test question, questionnaire, documentation. Based on the research results improving student learning outcomes trough Teams Games Tournament (TGT) models in the first cycle with a total percentage of $63,33 \%$, while in the second cycle a significant increase, amounting to $90,90 \%$. This shows the improvement of student learning outcomes from the first cycle to the second $27,57 \%$.
\end{abstract}

Keywords: Learning; Outcames; Teams Games Tournament 


\section{PENDAHULUAN}

Pendidikan merupakan suatu proses dalam mengembangkan potensi sumber daya manusia guna mewujudkan pembangunan yang berbudaya dan bermartabat, pendidikan di Indonesia diharapkan mampu menciptakan manusia yang mempunyai kepribadian yang tangguh, terampil, cerdas, dan berakhlak mulia serta cepat tanggap dan tangkas dalam menghadapi segala masalah kehidupan agar tidak tertinggal dengan negara lain. Sekolah melatih anak-anak memperoleh kecakapan-kecakapan seperti membaca, menulis, berhitung serta ilmu-ilmu yang lainnya, yang sifatnya mengembangkan kecerdasan dan pengetahuan. Untuk memperoleh kecakapan-kecakapan tersebut guru sebagai fasilitator membimbing siswa dalam proses belajar mengajar yang dilakukan di sekolah. Keberhasilan kegiatan dalam proses belajar mengajar di sekolah tidak hanya ditentukan oleh ketepatan guru mentransfer pengetahuannya, tetapi juga ditentukan oleh peran serta aktif dari siswa dalam proses pembelajaran.

Pembelajaran dapat dikaitkan sebagai hasil ingatan yang berpengaruh terhadap pemahaman hal ini terjadi ketika peserta didik harus belajar. Saat pembelajaran berlangsung guru harus merancang siswa dalam kelompok, seperti interaksi ruang kelas, sehingga dengan adanya situasi seperti ini dapat membantu setiap anggota kelompok belajar tentang efektivitas dalam bekerja sama untuk mencapai hasil belajar. Hasil belajar adalah kemampuankemampuan yang dimiliki siswa setelah menerima pengalaman belajarnya, ada beberapa yang mempengaruhi hasil belajar yaitu faktor internal dan faktor eksternal (Sudjana, 2009).

Berdasarkan pengamatan pada proses pembelajaran di kelas IV guru masih menggunakan model pembelajaran yang berfokus pada metode ceramah dan diskusi, sehingga siswa lebih banyak bermain dan gaduh dengan temannya dan ketika guru memberikan soal matematika, siswa tidak biasa mengerjakannya dan nilai yang diperoleh siswa kurang baik. Untuk menyelesaikan masalah yang berkaitan dengan pembelajaran tersebut, perlu diterapkan model pembelajaran inovatif untuk meningkatkan kualitas pembelajaran Matematika khususnya pada materi Bilangan Romawi pada siswa kelas IV Sekolah Dasar Negeri 6 Sintang melalui salah satu model pembelajaran Teams Games Tournament (TGT). Teams Games Tournament (TGT) merupakan pembelajaran kooperatif yang dikembangkan oleh Slavin (1995) untuk membantu siswa melihat kembali dan menguasai materi pembelajaran 
(Miftahul, 2013). Model TGT termasuk model pembelajaran yang efektif karena beragam variasi dari ceramah, kerja tim, permainan, turnamen dan penghargaan tim. Model ini melibatkan siswa secara aktif dalam pembelajaran. Guru lebih berperan sebagai konselor dan sumber kritik yang konstruktif (Wedyawati, 2014).

Model pembelajaran kooperatif merupakan salah satu jenis model pembelajaran yang mengutamakan adanya kerja sama, yakni kerja sama antara siswa dalam kelompok untuk mencapai tujuan pembelajaran. Pembelajaran kooperatif tipe TGT (Teams Games Tournaments) tidak hanya mengakomodasi usaha-usaha setiap individu anggota kelompok, tapi juga tetap memberikan penilaian terhadap usaha-usaha kerja kelompok (Noriyana, 2013). Slavin menemukan bahwa TGT berhasil meningkatkan skill-skill dasar, harga diri dan sikap penerimaan pada siswa-siswa lain yang berbeda. Pelaksanaan penelitian dengan menggunakan model pembelajaran Teams Games Tournament (TGT) menurut siswa akan lebih rileks dalam mengikuti pelajaran matematika karena mengandung unsur permainan dan pertandingan. Hal ini membuat peneliti tertarik menawarkan solusi dalam melakukan model pembelajaran yang sesuai dengan materi dan karakter peserta didik sehingga tercipta pembelajaran yang menyenangkan. Model pembelajaran Teams Games Tournament (TGT) dapat meningkatkan hasil belajar siswa dan melahirkan rangsangan untuk berfikir, yang akan sangat berguna bagi proses pengajaran jangka panjang, meningkatkan prestasi akademik dan kemampuan sosial, termasuk mengembangkan rasa harga diri hubungan interpersonal, keterampilan mengelola waktu dan sikap positif terhadap sekolah.

Melihat kondisi siswa di SD Negeri 6 Sintang kelas IV yang cenderung kurang mengoptimalkan model pembelajaran maka peneliti mengangkat judul "Penerapan Model Pembelajaran TGT Untuk Peningkatan Hasil Belajar Materi Bilangan Romawi Siswa Kelas IV Sekolah Dasar". Setelah melakukan observasi awal situasi di sekolah yang ditetapkan sebagai tempat penelitian adalah SD Negeri 06 Sintang. Sebagai situasi sosial sekolah ini terdapat orang-orang yang menjadi sasaran dari penelitian ini adalah siswa. Aspek-aspek yang menjadi fokus penelitian adalah : 1) Penerapan model pembelajaran Teams Games Tournament (TGT) pada materi Bilangan Romawi siswa kelas IV SD Negeri 06 Sintang. 2) Hasil belajar siswa dengan menggunakan model pembelajaran Teams Games Tournament (TGT) pada materi Bilangan Romawi siswa kelas IV SD Negeri 06 Sintang. 3) Respon siswa 
dengan menggunakan model pembelajaran Teams Games Tournament (TGT) pada materi Bilangan Romawi siswa kelas IV SD Negeri 06 Sintang.

\section{METODE PENELITIAN}

Metode penelitian pada dasarnya merupakan cara ilmiah untuk mendapatkan data dengan tujuan dan kegunaan tertentu (Sugiyono, 2015). Metode yang digunakan dalam penelitian ini adalah metode penelitian kualitatif. (Afrizal, 2015) menyatakan bahwa: penelitian kualitatif merupakan metode penelitian ilmu-ilmu sosial yang mengumpulkan dan menganalisis berupa kata-kata (lisan maupun tulisan) dan perbuatan-perbuatan manusia serta peneliti tidak berusaha menghitung atau mengkuantifikasikan data kualitatif yang telah diperoleh dan demikian tidak menganalisis angka-angka.

Bentuk penelitian ini merupakan Penelitian Tindakan Kelas. Dimana penelitian ini terjadi secara kolektif dalam suatu proses pembelajaran yang digunakan. Terjadi secara kolektif, karena dalam pelaksanaannya peneliti akan bekerja sama dengan pihak-pihak yang terlibat di dalam sekolah. Melalui penelitian tindakan kelas (PTK) ini diharapkan dapat mengatasi berbagai masalah yang nyata dalam proses pembelajaran di kelas. Penelitian tindakan kelas (PTK) adalah pencermatan dalam bentuk tindakan terhadap kegiatan belajar yang sengaja dimunculkan dan terjadi dalam sebuah kelas secara bersamaan (Suyadi, 2010).

\section{HASIL DAN PEMBAHASAN}

\section{Penerapan Model Pembelajaran Teams Games Tournament (TGT)}

\section{Aktivitas Guru Siklus I}

Hasil pengamatan aktivitas guru siklus I, adapun peneliti merekap hasil pengamatan aktivitas guru siklus I dalam dua kali pembelajaran dapat dilihat pada Tabel 1.

Tabel 1. Persentase Aktivitas Guru Siklus I

\begin{tabular}{ccccc}
\hline \multicolumn{4}{c}{ Persentase Pelaksanaan } & Rata-rata \\
\cline { 1 - 3 } Prekuensi & $\%$ & Pertemuan II & \\
14 & $77,77 \%$ & Frekuensi & $\%$ & 83,32 \\
\hline
\end{tabular}


Berdasarkan Tabel 1 diketahui bahwa pelaksanaan proses pembelajaran dengan model pembelajaran Teams Games Tournament mengalami peningkatan dari pertemuan I ke pertemuan II.

\section{Aktivitas Guru Siklus II}

Pengamatan pertama dilaksanakan tanggal 9 Februari 2019, sedangkan pengamatan kedua dilaksanakan pada tanggal 16 Februari 2019. Selanjutnya hasil observasi aktivitas guru pada siklus II ditampilkan pada Tabel 2.

Tabel 2. Persentase Aktivitas Guru Siklus II

\begin{tabular}{ccccc}
\hline \multicolumn{3}{c}{ Persentase Pelaksanaan } & \multirow{2}{*}{ Rata-rata } \\
\cline { 1 - 3 } Frekuensi & $\%$ & Frekuensi & $\%$ & \\
17 & $94,44 \%$ & 18 & $100 \%$ & 97,22 \\
\hline
\end{tabular}

Berdasarkan Tabel 2 diketahui bahwa pelaksanaan proses pembelajaran dengan model pembelajaran Teams Games Tournament mengalami peningkatan dari pertemuan I ke pertemuan II. Hal ini menunjukkan bahwa proses pembelajaran Teams Games Tournament dapat dilaksanakan dengan baik oleh guru. Adapun aktivitas guru yang belum tercapai pada siklus II yaitu tidak maksimal dalam menyimpulkan pembelajaran. Aktivitas guru pada siklus II menjadi lebih baik dibandingkan siklus I.

\section{Aktivitas Siswa Siklus I}

Hasil pengamatan aktivitas siswa siklus I, adapun peneliti merekap hasil pengamatan aktivitas siswa siklus I dalam dua kali pertemuan yang dapat dilihat pada Tabel 3.

Tabel 3. Persentase Aktivitas Siswa Siklus I

\begin{tabular}{ccc}
\hline \multicolumn{2}{c}{ Persentase Pelaksanaan } & Rata-rata \\
\cline { 1 - 2 } Pertemuan I & Pertemuan II & \\
$61,07 \%$ & $63,17 \%$ & $62,12 \%$ \\
\hline
\end{tabular}

Bedasarkan Tabel 3 hasil observasi siswa siklus I pertemuan I yaitu memperoleh $61,07 \%$, pertemuan II yaitu memperoleh $63,17 \%$ dan memperoleh rata-rata yaitu $62,12 \%$. Berdasarkan hasil persentase tersebut menunjukkan bahwa aktivitas siswa dalam proses 
pembelajaran menggunakan model pembelajaran Teams Games Tournament untuk tindakan siklus I tergolong kategori cukup.

\section{Aktivitas Siswa Siklus II}

Hasil pengamatan aktivitas siswa siklus II, adapun peneliti merekap hasil pengamatan aktivitas siswa siklus II dalam dua kali pertemuan dapat dilihat pada Tabel 4.

Tabel 4. Persentase Aktivitas Siswa Siklus II

\begin{tabular}{ccc}
\hline \multicolumn{2}{c}{ Persentase Pelaksanaan } & \multirow{2}{*}{ Rata-rata } \\
\cline { 1 - 2 } Pertemuan I & Pertemuan II & \\
\hline $85,31 \%$ & $89,97 \%$ & $87,64 \%$ \\
\hline
\end{tabular}

Bedasarkan Tabel 4 hasil observasi siswa siklus II pertemuan I yaitu memperoleh $85,31 \%$, pertemuan II yaitu memperoleh $89,97 \%$ dan memperoleh rata-rata yaitu $87,64 \%$. Berdasarkan hasil persentase rata-rata tersebut menunjukkan bahwa aktivitas siswa dalam proses pembelajaran menggunakan model pembelajaran Teams Games Tournament untuk tindakan siklus II tergolong kategori sangat baik.

\section{Perbandingan Aktivitas Siswa Siklus I dan II}

Dari pemaparan hasil observasi siswa siklus I dan II, terjadi peningkatan yang signifikan. Hal tersebut dapat dibuktikan melalui hasil observasi yang dilaksanakan pada saat penelitian, maka dapat disajikan berupa diagram yang dapat dilihat pada Gambar 1 .

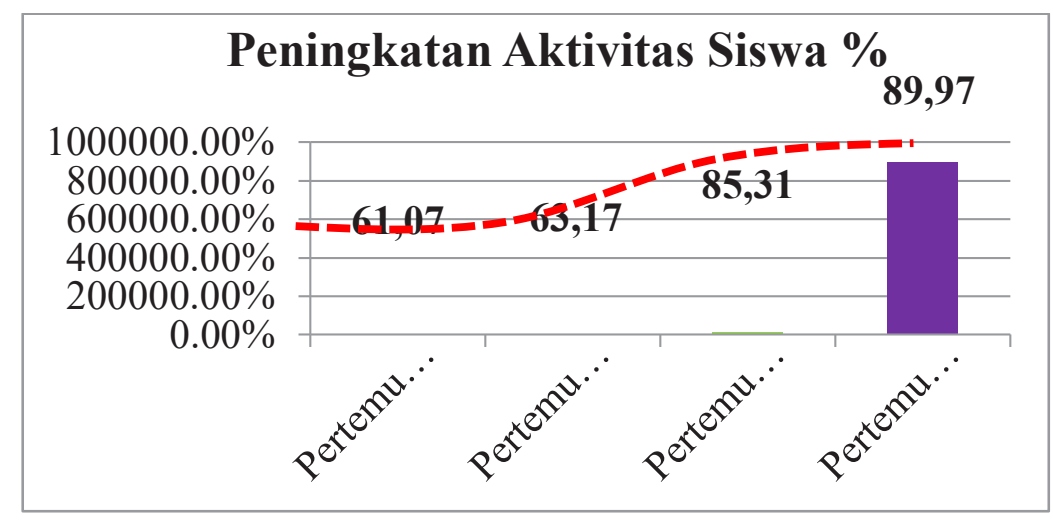

Gambar 1. Peningkatan Aktivitas Siswa 


\section{Hasil Belajar Siswa}

\section{Hasil Belajar Siklus I}

Hasil belajar siswa siklus I, adapun peneliti merekap hasil belajar siklus I dapat dilihat pada Tabel 5 .

Tabel 5. Hasil Belajar Siklus I

\begin{tabular}{clc}
\hline No & \multicolumn{1}{c}{ Hasil Belajar } & Siklus I \\
\hline 1 & Kriteria ketuntasan minimum siswa & 60 \\
2 & Nilai tertinggi & 80 \\
3 & Nilai terendah & 23,33 \\
4 & Nilai rata-rata & 57,16 \\
5 & Jumlah siswa yang tuntas & 21 \\
6 & Jumlah siswa yang tidak tuntas & 12 \\
7 & Persentase ketuntasan klasikal & 63,33 \\
8 & Persentase minimum ketuntasan klasikal & 85 \\
9 & Kategori ketuntasan secara klasikal & Tidak tuntas \\
\hline
\end{tabular}

Tabel 5 menunjukkan bahwa nilai rata-rata dari seluruh siswa 57,16 dengan persentase ketuntasan klasikal yang dicapai 63,33\%. Hasil tersebut memberikan kesimpulan bahwa belum memenuhi syarat ketuntasan belajar klasikal. Ketentuan ketuntasan belajar klasikal dicapai sekurang-kurangnya 85\% dari jumlah siswa yang memperoleh nilai 60 sesuai dengan KKM yang telah ditetapkan.

\section{Hasil Belajar Siklus II}

Hasil belajar siswa siklus II, adapun peneliti merekap hasil belajar siswa siklus II dapat dilihat pada Tabel 6 .

Tabel 6. Hasil Belajar Siklus II

\begin{tabular}{clc}
\hline No & \multicolumn{1}{c}{ Hasil Belajar } & Siklus II \\
\hline 1 & Kriteria ketuntasan minimum siswa & 60 \\
2 & Nilai tertinggi & 100 \\
3 & Nilai terendah & 30 \\
4 & Nilai rata-rata & 69,99 \\
5 & Jumlah siswa yang tuntas & 30 \\
6 & Jumlah siswa yang tidak tuntas & 3 \\
7 & Persentase ketuntasan klasikal & 90,90 \\
8 & Persentase minimum ketuntasan klasikal & 85 \\
9 & Kategori ketuntasan secara klasikal & Tuntas \\
\hline
\end{tabular}


Tabel 6 menunjukkan bahwa nilai rata-rata seluruh siswa adalah 69,99 dengan persentase ketuntasan klasikal 90,90. Hasil tersebut memberikan kesimpulan bahwa sudah memenuhi syarat ketuntasan belajar klasikal. Ketentuan ketuntasan belajar klasikal dicapai sekurang-kurangnya $85 \%$ dari jumlah siswa yang memperoleh nilai 60 sesuai dengan KKM yang telah ditetapkan.

\section{Perbandingan Peningkatan Hasil Belajar Siswa Siklus I dan Siklus II}

Dari pemaparan sebelumnya mengenai peningkatan hasil belajar siklus I dan siklus II, maka telah diketahui peningkatan yang signifikan dari siklus I ke Siklus II. Berdasarkan hasil penelitian yang telah dilaksanakan, maka dapat dilihat peningkatan yang signifikan dari siklus I ke siklus II, yang mana hasil penelitian pada siklus I mendapat hasil yang kurang memadai. Kemudian hasil penelitian pada siklus II, mendapat hasil yang sangat memadai. Hal tersebut dapat dilihat pada tabel dan gambar diagram yang disajikan dalam hasil penelitian.

\section{Angket Respon Siswa Setelah Penerapan Model Pembelajaran Teams Games Tournament (TGT)}

Setelah lembar angket dikumpulkan, maka data hasil angket respon siswa mengenai peningkatkan hasil belajar siswa dengan menggunakan model pembelajaran Teams Games Tournament (TGT) pada materi bilangan romawi kelas IV SD Negeri 06 Sintang, peneliti merekap hasil angket respon siswa dapat dilihat pada tabel 7.

Tabel 7. Rekapitulasi Hasil Angket Respon Siswa

\begin{tabular}{ccc}
\hline Pernyataan & Jumlah & Persentase \\
\hline $\mathbf{1}$ & 147 & 87,87 \\
$\mathbf{2}$ & 152 & 92,12 \\
$\mathbf{3}$ & 152 & 92,12 \\
$\mathbf{4}$ & 148 & 89,69 \\
$\mathbf{5}$ & 151 & 91,51 \\
$\mathbf{6}$ & 150 & 90,90 \\
$\mathbf{7}$ & 152 & 92,12 \\
$\mathbf{8}$ & 150 & 90,90 \\
$\mathbf{9}$ & 152 & 92,12 \\
$\mathbf{1 0}$ & 150 & 90,90 \\
\hline Jumlah Skor Maksimal/Soal & 165 \\
\hline Jumlah Skor Maksimal/Siswa & 50 \\
\hline \multicolumn{2}{c}{ Jumlah seluruh skor } \\
\hline \multicolumn{2}{c}{21} \\
\hline
\end{tabular}




\begin{tabular}{cc}
\hline Jumlah seluruh skor yang diperoleh & 1504 \\
\hline Persentase & 91,15 \\
\hline Kriteria & Sangat Baik \\
\hline
\end{tabular}

Pemilihan model pembelajaran yang tepat merupakan kunci keberhasilan dalam sebuah proses dan tujuan dari pembelajaran (Wedyawati \& Gamilina, 2018) dikarenakan dalam pembelajaran menggunakan model pembelajaran Auditory Intellectually Repetition (AIR) siswa terlibat aktif dalam proses belajar mengajar dan dapat melakukan interaksi dengan temannya serta dapat saling bertukar pikiran saat melakukan diskusi, dapat praktik secara langsung sehingga siswa dapat pengalaman yang nyata dan juga dalam proses pembelajaran menggunakan model siswa dapat belajar tanpa tekanan dan dapat merasa santai dan bergembira.

Dalam pembelajaran matematika salah satu pendekatan yang dapat digunakan adalah pendekatan kontekstual, dimana pembelajaran lebih memperhatikan potensi, situasi, dan kondisi dari siswa, serta sarana pembelajaran dan tujuan yang ingin dicapai. Kenyataan dalam proses pembelajaran sebagaian besar siswa tidak mampu menghubungkan antara apa yang dipelajari dengan pemanfaatanya dalam kehidupan sehari-hari. Hal tersebut disebabkan pemahaman akademik siswa hanya sesuatu yang abstrak dan belum dialami dalam kehidupan sehari-hari, baik di lingkungan sekolah, keluarga, maupun lingkungan masyarakat (Wedyawati, Kristianus, \& Sri Rejeki H., 2017). Konsep yang siswa dapatkan sudah ada dalam kehidupan sehari-hari, tetapi siswa tidak pernah menyadarinya. Hal tersebut disebabkan karena pembelajaran yang diterima hanyalah pembelajaran yang bersifat hafalan semata dan tidak diikuti dengan pemahaman atau pengertian yang mendalam yang bisa diterapkan ketika siswa berada di lingkungan luar atau lingkungan baru.

\section{SIMPULAN}

Berdasarkan hasil analisis data dapat disimpulkan secara umum bahwa penggunaan model pembelajaran Teams Games Tournament (TGT) pada materi Bilangan Romawi berhasil meningkatkan hasil belajar pada siswa kelas IV SD N 06 Sintang. Hal ini dapat dibuktikan dari hasil observasi siklus I dan siklus II dan disimpulkan bahwa penggunaan model pembelajaran Teams Games Tournament (TGT) dalam meningkatkan hasil belajar pada pembelajaran matematika materi bilangan romawi kelas IV Sekolah Dasar 06 telah 
mencapai tujuan pembelajaran sesuai dengan yang diharapkan. Berdasarkan hasil penilaian yang dilakukan menunjukan bahwa penggunaan model pembelajaran Teams Games Tournament (TGT) pada materi bilangan romawi mengalami peningkatan setiap siklus. Pada siklus I dengan jumlah persentase sebesar 63,33 sedangkan pada siklus II terjadi peningkatan yang signifikan, yaitu sebesar 90,90. Hal ini menunjukan terjadi peningkatan hasil belajar siswa dari siklus I ke siklus II sebesar 27,57.

Saran dari penelitian ini adalah bagi siswa, diharapkan agar selalu memiliki sikap-sikap yang dapat menghargai guru dan mengembangkan nilai-nilai yang ada untuk dipraktikkan serta siswa diharapkan mampu mengembangkan potensinya secara optimal.

\section{DAFTAR PUSTAKA}

Afrizal. (2015). Metode Penelitian Kualitatif. Jakarta: Raja Grafindo Persada.

Miftahul, H. (2013). Model-model Pengajaran dan Pembelajaran. Yogyakarta: Pustaka Timur.

Noriyana, M. (2013). Penerapan Pembelajaran Kooperatif Tipe Teams Games Tournament (TGT) untuk Meningkatkan Aktivitas dan Hasil Belajar Matematika pada Materi Segiempat di Kelas VII A SMPN 3 Paringin. Jurnal Quantum, Jurnal Inovasi Pendidikan Sains, Volume 4 Nomor 1, 79-84.

Sudjana. (2009). Penilaian Hasil Proses Belajar Mengajar. Bandung: Remaja Rosda Karya. Sugiyono. (2015). Metode Penelitian Pendidikan Pendekatan Kuantitatif, Kualitatif, R\&D. Bandung: Alfabeta .

Suyadi. (2010). Panduan Penelitian Tindakan Kelas. Jogjakarta: Diva Press.

Wedyawati, N. (2014). Pembelajaran IPA Bervisi SETS untuk Peningkatan Prestasi Belajar dan Peningkatan Sikap Tanggap Bencana Siswa Kelas IV SD Swasta \& Negeri (SD Kristen Imanuel Nanga PInoh \& SD Negeri 1 Nanga Pinoh). Vox Edukasi: Jurnal Ilmiah Ilmu Pendidikan Volume 5 Edisi 2, 115-124.

Wedyawati, N., \& Gamilina, P. (2018). Penerapan Model Auditory Intellectually Repetition (AIR) terhadap Aktivitas dan Hasil Belajar Kognitif siswa Sekolah Dasar. KEGURU: Jurnal Ilmu Pendidikan Dasar Volume 2 Edisi 2 , 155-162. 
Wedyawati, N., Kristianus, \& Sri Rejeki H., A. (2017). Penerapan Strategi Pembelajaran REACT berbantuan Alat Peraga terhadap Hasil Belajar Kognitif Matematika. Jurnal Edukasi: Jurnal Pendidikan Jilid 15 Edisi 1, 96-104. 